\title{
Low Inspiratory Pressure Alarm Device
}

National Cancer Institute

\section{Source}

National Cancer Institute. Low Inspiratory Pressure Alarm Device. NCI Thesaurus. Code C49819.

A device designed to signal the occurrence of a low pressure event associated with a mechanical ventilation device. 